\title{
ON AN UNDESCRIBED SPECIES OF CRYPTOCARYA FROM EASTERN AUSTRALIA.
}

\author{
By R. T. Baker, F.L.S., Curator, Technological Museum, \\ SYDNEY.
}

(Plate $\mathrm{xxx}$.

\section{Cryptocarya feEtida, sp.nov.}

A small tree from 30 to 50 feet high, and 9 inches in diameter, so far as at present known; glabrous, except the inflorescence, which is minutely rusty or silvery.

Leaves glabrous on both sides, ovate to oblong, acuminate or obtuse, mostly 4 to $\check{5}$ inches, rarely 6 inches long, from $1 \frac{1}{2}$ to $2 \frac{1}{2}$ inches broad, rarely 3 inches, paler on the underside but not glaucous, not shining, although perhaps a little so on the under surface, rigid, thick, almost coriaceous, margins slightly recurved, reticulations well marked and coarsely so on the undersurface. The leaves have irregularly scattered over the upper surface black spots or markings, probably caused by sudden changes of temperature, as they do not appear to be caused by any organism.

Panicled cymes axillary or terminal, solitary, but occasionally in twos or threes; flowers numerous, hoary pubescent, smaller than those of $C$. patentinervis F.v.M., but larger than those of $C$. glaucescens R.Br. Perianth segments about 1 line long, the tube turbinate half the length of the tube. Glands shortly stipitate, much shorter than the inner or outer stamens, and not attached to either the inner or outer series of these organs. Staminodia three, about half the length of the stamens. Fruiting perianth globular, 4 to 5 lines in diameter, mostly with a "bloom."

Hab.--Moreton Bay (Allan Cunningham); Ballina (W. Bäuerlen). 
The earliest herbarium specimen of this species extant is in the Kew Herbarium. This was collected by Allan Cunningham at Moreton Bay in 1828.

The material collected by W. Bäuerlen was under observation for some time, and was at first placed provisionally as $C$. glaucescens, var., as it was thought it might eventually work out as one of the varieties of that species enumerated by Bentham (B.Fl. Vol.v. 297).

As material of these varieties (sic) was identified, it became apparent that some of them were distinct species; and Maiden and Baker* restored Meissner's C. microneura to specific rank.

When examining the Cryptocaryas in the Kew Gardens herbarium recently, it appeared to me that more than one distinct species was included by Bentham under the name $C$. glaucescens. It must not be forgotten, however, that Bentham laboured under the great disadvantage of not knowing the trees in the field, and so had only dried specimens upon which to make his determinations.

As Bentham's type C.glaucescens (loc. cit.) is identical with what is so regarded in Australian herbaria, the way is thus clear to differentiate the various forms at present placed under that species.

C. glaucescens (type) has an extensive range along the eastern coast, is constant in morphological characters, and is distinct from any other known Cryptocarya; and, so far, I have been unable to trace any intermediary forms.

This new species differs altogether from C. glaucescens in the shape of fruit, also shape, size, texture and venation of the leaves, and in inflorescence.

C. microneura Meissn. has thin, long, narrow leaves, and an elongated fruit.

C. patentinervis F.v.M. has also long lanceolate leaves and a very distinct cymose inflorescence, and an oblong fruit.

* Proc. Linn. Soc. N.S.W. 1895, p.515. 
C. obovata R.Br., differs, more especially in its leaf characters, as well as in the form of its fruits; the inflorescence, however, is similar.

The timbers of all the above show scarcely any distinct specific differences.

In shape and reticulation of leaf $C$. fretida approaches more nearly C. Mackinoniana F.v.M., and in botanical sequence it should perhaps come between that species and C. obovata R.Br.

Meissner's $C$. Cunninghamii is only a slightly larger-flowered form of the typical $C$. ylaucescens; and the same author's $C$. Moretoniana has shiny leaves and a finer reticulation, features that do not appear in C. fretida.

Apart from the other systematic characters above enumerated, the fruits are quite unlike those of any other described species.

It might also be added that it was not until the material had been compared with that at Kew Gardens Herbarium that I was prepared to describe it as new.

Economics.--Timber not seen to any size, but most of the Cryptocaryas are famed for their hard, durable wood, and this one probably is no exception.

One of its economics is worthy the attention of the apiarist, for Mr. Bäuerlen writes concerning the tree :-- " The flowers have a very offensive odour, but are nevertheless very much visited by bees, wasps, and other insects."

I have to acknowledge my indebtedness to Sir William Thiselton-Dyer, K.C.M.G., \&c., \&c., Director of the Royal Botanical Gardens, Kew, for his kindness in giving me free access to the Kew herbarium and the use of the material there for comparison.

\section{EXPLANATION OF PLATE XXX.}

Cryptocarya fotida, sp.n.

Fig. 1.-Twig showing inflorescence and leaves.

Fig. 2.-Bud (enlarged).

Fig. 3.-Expanded flower (enlarged).

Fig. 4. -Fruit. 


\section{$2 \mathrm{BHL}$ Biodiversity Heritage Library}

Baker, Richard T. 1906. "On an undescribed species of Cryptocarya from eastern Australia." Proceedings of the Linnean Society of New South Wales 30, 517-519. https://doi.org/10.5962/bhl.part.12914.

View This Item Online: https://www.biodiversitylibrary.org/item/30106

DOI: https://doi.org/10.5962/bhl.part.12914

Permalink: https://www.biodiversitylibrary.org/partpdf/12914

\section{Holding Institution}

MBLWHOI Library

\section{Sponsored by}

MBLWHOI Library

\section{Copyright \& Reuse}

Copyright Status: NOT_IN_COPYRIGHT

This document was created from content at the Biodiversity Heritage Library, the world's largest open access digital library for biodiversity literature and archives. Visit BHL at https://www.biodiversitylibrary.org. 